\title{
THE STUDY OF BEER QUALITY WITH THE REDUCED TOXIC EFFECT
}

\author{
Nataliya Penkina \\ Department of merchandise in customs \\ Kharkiv State University of Food Technology and Trade \\ 333 Klochkivska str., Kharkiv, Ukraine, 61051 \\ penkina-nataliya@rambler.ru \\ Larisa Tatar \\ Department of Commodity, quality management and environmental safety \\ Kharkiv State University of Food Technology and Trade \\ 333 Klochkivska str., Kharkiv, Ukraine, 61051 \\ tornado.1972@mail.ru \\ Victoria Kolesnyk \\ Department of Commodities in customs \\ Kharkiv State University of Food Technology and Trade \\ 333 Klochkivska str., Kharkiv, Ukraine, 61051 \\ vkol240584@gmail.com \\ Tetiana Karbivnycha \\ Department of Commodity, quality management and environmental safety \\ Kharkov State University of Food Technology and Trade \\ 333 Klochkivska str., Kharkiv, Ukraine, 61051 \\ tanya280372@rambler.ru \\ Tetiana Letuta \\ Department of Commodity and expertise of goods \\ Kharkov State University of Food Technology and Trade \\ 333 Klochkivska str., Kharkiv, Ukraine, 61051 \\ Lettanya@ukr.net
}

\footnotetext{
Abstract

There was grounded the expedience of using unconventional vegetable raw material, namely Pinus sylvestris needle that partially replaced hop for beer enrichment. The optimal parameters of extraction of Pinus sylvestris needle relative to anti-oxidant activity of extract: hydromodulus 1:20, temperature $60^{\circ} \mathrm{C}$, extraction $30 \mathrm{~min}$. The needle extract has pure smell, harmonic refreshing taste with needle note. The content of ascorbic acid in extraction is $0,275 \mathrm{mg} / 100 \mathrm{~g}$, antioxidant activity $-202,3 \mathrm{C} / 100 \mathrm{~g}$. The quantitative ratio of hop and pine needle in beer receipt was determined by the way of mathematical modeling. Quantitative content of Pinus sylvestris needle is no more than $20 \%$ by mass from the rated norm of hop that is enough for preserving hop bitterness and smell. The receipt of beer, including Pinus sylvestris needle, was elaborated. The quality parameters of ready drink were studied. The addition of needle increases the beer gustatory properties, decreases methanol content. The content of ascorbic acid in ready drink is $3,52 \mathrm{mg} / 100 \mathrm{~g}$. Antioxidant activity of elaborated beer is $178,1 \mathrm{C} / 100 \mathrm{~g}$ that determines its high biological value.

The influence of beer with needle extract on antioxidant system of organism of biological objects was assessed. Under conditions of acute pathological condition the beer with needle extract decreases oxidative influence of drink on brain of biological objects. The beer "Smaragd" decreases toxic effect on organism of living creature due to its antioxidant properties.

The introduction of needle extract that includes vegetable antioxidants in beer is the one of the ways to increase antioxidant capacity of ready drink. It opens the prospect of studies, directed on elaboration of arrangements of stabilization of different sorts of beer. The studies may be introduced in production that has positive effect on ready product quality.

Keywords: beer, pine needle, antioxidant capacity, oxidative stress, toxicity, liver homogenate, pro-antioxidant markers. 


\section{Introduction}

The addition of antioxidants in beer allows decrease oxidative and toxic effect of alcohol on human organism [1]. The leaves of conifers are the source of natural antioxidants, have the high food, biological value and may be used as hop alternative. Beer, produced with addition of vegetable raw material has its advantages: functional directive effect, improved organoleptic and physical-chemical parameters, more storage life [2, 3]. The elaboration of beer with addition of needle extract gives a possibility to get new original sorts of beer and widen the assortment of beer branch.

The realized studies were aimed at estimation of influence of Pinus sylvestris needle extract on formation of the ready beer quality. It allows get a drink with high antioxidant properties and decrease the negative effect of alcohol on human organism.

\section{Materials and Methods}

The water extract of unconventional vegetable raw material - Pinus sylvestris needle was chosen for partial replacement of hop and beer enrichment with biologically active substances.

For realization of experiment the samples of pine needle were gathered in early winter period, because in this time the maximal accumulation of biologically active substances in them takes place [4]. The raw material corresponded to the requirements TC U 15.8-31062507-022:2009 "Vegetable natural raw material for production of diet additives".

The simplest way of extraction was selected to get the needle extract - maceration. The material, subjected to extraction - freshly gathered needle of Pinus sylvestris; extractant - water. Hydromodulus, temperature and duration of extraction process were set experimentally using mathematical modeling.

The gotten water extract of Pinus sylvestris needle is presented on the Fig. 1.

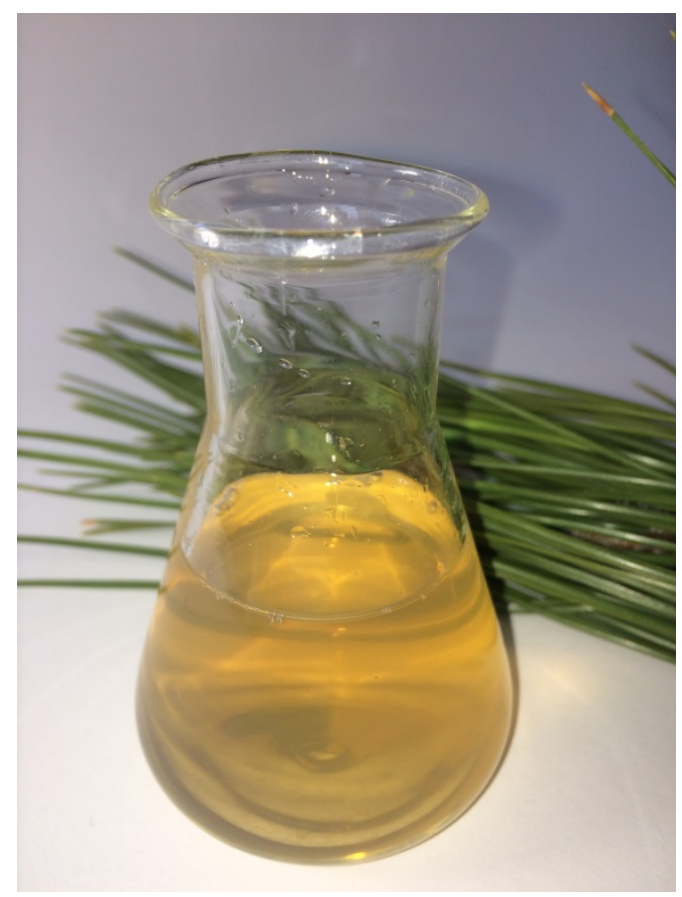

Fig. 1. Water extract of Pinus sylvestris needle

2. 1. The study of the quality parameters of needle extract and beer, elaborated with its addition

The organoleptic parameters were estimated by the method of sensor analysis [5].

The mass share of dry substances in initial wort and mass share of alcohol in beer were estimated by aerometric and refractometric methods [6]. The acidity was estimated by direct titration of sample [7], color - by colorimetric method [8]. Mass share of carbon dioxide was studied by 
measuring of pressure in gas space above the sample in corked utensil, stability - by visual observation of turbidity or sediment [9].

The antioxidant capacity, based on coulometric titration of studied sample by bromine, was estimated in water extract and ready beer. The content of ascorbic acid was estimated by iodometric method [10].

The identification of micro-components in beer was estimated by the standard gasochromatographic method, standardized for vodka, ethyl alcohol and water-alcoholic mixtures and possible for beer samples $[11,12]$.

For express-method of methanol revelation the colored screening-sample by oxidation reaction of methanol to formaldehyde is recommended. The negative reaction testifies to falsification of beer, because methanol is a product of yeast fermentation. The positive one needs estimation of methanol concentration by chromatographic method together with other micro-components.

The chromatograms of beer samples were gotten on chromatograph "Crystal-2000M" (Russia) using flaming-ionizing detector.

The experimental data were processed by the methods of variational statistics using the standard package of computer programs "Statistica 6.0" (England) [13] with Student t-criterion and MathCAD.

\section{2. The study of quality parameters of needle extract and ready beer, elaborated with} its addition, on the organism of biological objects

The frequent taking of alcohol results in intensification of processes of free radicals and prooxidants creation. Thus, it was expedient to study the influence of beer product with pine needle under conditions of increased oxidation.

The subchronic disorder of antioxidant system of organism was reproduced on the model of oxidative stress. The experiment was carried out on 36 white non-linear rats with mass $220-250 \mathrm{~g}$ of both sexes, divided in six groups (Table 1). For relevant interpretation of the results the experiment included groups, in which the influence of refined water, beer, produced by classic technology, and beer with Pinus sylvestris needle was compared under ordinary conditions and under conditions of oxidative stress.

Table 1

Exposition of experimental groups

\begin{tabular}{|c|c|c|c|}
\hline Group № & Introduced substance & Dose g/kg & Term, days \\
\hline \multicolumn{4}{|c|}{ Animals of intact control } \\
\hline 1 & Refined water & & \\
\hline 2 & Beer, produced by classic technology & 15 & 14 \\
\hline 3 & Beer with Pinus sylvestris needle extract & & \\
\hline
\end{tabular}

Animals with experimentally reproduced oxidative stress

4

\section{Refined water}

Beer, produced by classic technology

Beer with Pinus sylvestris needle extract

Oxidative stress was modeled according to the standard methodology (glucocorticoid-induced oxidative stress) by everyday intra-abdominal administration of prednisolone in dose $50 \mathrm{mg} / \mathrm{kg}$ during 14 days. In three hours after administration of preparation the studied drinks were adminis- 
tered in dose $15 \mathrm{~g} / \mathrm{kg}$, equivalent to the mean quantity of beer, taken by human at a time. The intact animals were administered with correspondent quantity of refined water. It was expedient to study the influence of aforesaid drinks on prooxidant balance of liver under conditions of worsened state of organism. At 14-th day the animals were excluded from experiment and their liver homogenate was studied for quantitative content of antioxidant (RG, catalase) and prooxidant (DC, TBA-reactants) markers according to the standard methods:

- the estimation of diene conjugates (DC) level was carried out according to the method of Stalna I. D. in modification of Skornyakov V. I. [14, 15];

- the estimation of TBA-reactants level was carried out according to Uchiyma M. \& Michara M. Methd in modification of Volchegorsky I. A. by the test with thiobarbituric acid (TBA) [16, 17];

- the content of restored glutathione (RG) in skin was estimated by spectrophotometric method with Ellman reagent [18];

- the catalase activity was estimated by the method, based on hydrogen peroxide $\left(\mathrm{H}_{2} \mathrm{O}_{2}\right)$ ability to create the stable colored complex with molybdenum salts [19, 20].

The markers of prooxidant balance of cells testify to the activity of free radical processes, antioxidant markers - to the activity of enzymatic chain of antiradical protection of cells. The classic markers of prooxidant-antioxidant balance are DC, TBA-reactants, RG and catalase, at the same time the high values of RG and catalase and low values of DC, TBA-reactants testify to the normal status of the cell, in opposite case - to activation of peroxide oxidation of lipids and membranodestruction.

The content of diene conjugates in homogenate of liver tissues was calculated by the formula:

$$
\mathrm{C}(\mathrm{Tcmol} / \mathrm{g})=227,27 \times \text { Esample }
$$

where C - DC content; Esample - optic density of studied sample.

The content of TBA-active products in liver tissues homogenate of studied animals was calculated by the formula:

$$
\mathrm{C}(\mathrm{mcmol} / \mathrm{g})=\frac{\text { Esample }}{1,56 \cdot 10^{5}} \times 2 \cdot 10^{6}
$$

where $\mathrm{C}$ - the content of TBA-active products; Esample - optic density of studied sample.

The calculation of restored glutathione in liver tissues homogenate was realized according to the formula:

$$
\mathrm{C}(\mathrm{mcmol} / \mathrm{g})=\text { Esample } \times 1094 \mathrm{mg} \% \text {, }
$$

where $\mathrm{C}$ - the content of glutathione; Esample - optic density of studied sample.

The catalase activity in liver tissues homogenate was calculated by the formula:

$$
\operatorname{Ecat}(\mathrm{mM} / 1 \times \min )=\frac{(\text { Acontr }- \text { Astud })}{\mathrm{K} \times \mathrm{t}} \times \mathrm{V} \cdot 10^{6},
$$

where E - catalase activity; Acontr and Astud - optic density (extinction) of blank and studied sample; V - volume of sample (3,02 ml); $\mathrm{t}$ - time of incubation (10 min); K - coefficient of millimolar extinction of hydrogen peroxide, $22,2 \cdot 10^{3} \mathrm{mM}^{-1} \cdot \mathrm{cm}^{-1}$.

The influence of studied object on the functional state of organism under conditions of acute pathological state was studied on the model of acute normobaric hypoxia. 18 white non-linear mice with mass 20-30 g of different sex, divided in three experimental groups (six animals in each one) were used in experiment. During 14 days before hypoxia modeling the mice were intra-abdominal- 
ly administered with $15 \mathrm{~g} / \mathrm{kg}$ of water, ordinary beer and beer with pine needle extraction once a day. The research on the model of acute normobaric hypoxia was carried out by keeping animals in close special container with volume $200 \mathrm{~cm}^{3}$; maximal life duration and thanatogenesis symptoms were registered [21].

The received experimental data were statistically processed by the method of variational statistics using the standard package of programs "Statistica 6.0" with Mann-Whitney U-criterion [13]. The reliable differences between groups were considered as ones with significance level $p<0,05$.

\section{Experimental procedures}

For receiving the water extract, Pinus sylvestris needle was comminuted in crusher to the particles size 3,0-5,0 $\mathrm{mm}$. The value of antioxidant capacity of water extract was taken as a parameter of technological process. Extraction was realized according to the received optimal conditions: hydromodulus $1: 20$, temperature $60^{\circ} \mathrm{C}$, time of extraction $30 \mathrm{~min}$. The ready extract was cooled to the temperature $8 \ldots 10^{\circ} \mathrm{C}$ and filtered. Mass share of dry substances in ready needle extract was 3,25\%.

The biological value and organoleptic parameters of needle extract were estimated (Table 2).

Table 2

Organoleptic parameters and biological value of water extract of Pinus sylvestris needle

\begin{tabular}{cc}
\hline Parameter & Characteristic \\
Appearance & Transparent liquid with golden color \\
Smell & Clear, with expressed needle smell \\
Flavor & Harmonic, refreshing with needle note \\
Ascorbic acid content, $\mathrm{mg} / 100 \mathrm{~g}$ & 0,275 \\
Antioxidant activity, $\mathrm{C} / 100 \mathrm{~g}$ & 202,3
\end{tabular}

The extract was introduced in wort at the stage of main fermentation, because it gives the minimal loss of aromatic substances.

Technological process consists of the following operations: preparation of jam, its saccharification, filtration, boiling of wort, cooling and introduction of yeast, fermentation of wort, after-fermentation of new beer and bottling of beer "Smaragd". The preparation of beer is realized according to existent "Technological instruction on production of malt and beer" TI 18-6-47-85 and "Technological instruction for production of 10 \% lager "Smaragd" TI 14297558-340:2016, elaborated in Kharkov state university of food and trade (Ukraine). The water extract of Pinus sylvestris needle was added in norm $600-620 \mathrm{ml} /$ dal of wort and fermented by brewer's bottom yeast at temperature $8 \ldots 10^{\circ} \mathrm{C}$. The main fermentation was realized to the content of visible extract 2,5-2,8 \%. Fermentation and after-fermentation of beer took place for no less than 25 days.

The clarification (filtration) of beer was carried out at kieselguhr candle filter FK-120 (Destila, Czech Republic). At insufficient beer satiation with carbon dioxide the additional carbonization was carried out at temperature $0 \ldots 2^{\circ} \mathrm{C}$. After maturation the beer was pumped in forfases for future storage and bottling. Pasteurization is realized in automatic regime according to the technological program of process.

The receipt of $10 \%$ lager Smaragd" is elaborated with addition of water extract of Pinus sylvestris needle (Table $\mathbf{3}$ ).

The solution about the optimal ratio of ingredients in beer receipt was made by the method of mathematical modeling and organoleptic assessment. The quantitative ratio of hop and Pinus sylvestris needle is no more than $20 \%$ by mass from rated norm of hop that is enough for preserving bitterness and hop smell. 
Table 3

The receipt content of $10 \%$ lager "Smaragd", raw material consumption for 1 dal of beer

\begin{tabular}{cc} 
Ingredients & Content of ingredients \\
\hline Brewing barley light malt & $100 \%$ \\
Bottom yeast & $50-100 \mathrm{~g} / \mathrm{dal}$ \\
Hop granules, norm of bitter substances & $\mathrm{Gf}=0,4-0,7 \mathrm{~g} / \mathrm{dal}$ \\
Pinus sylvestris needle extract & $600-620 \mathrm{ml} / \mathrm{dal}$ \\
Technological water & Consumption
\end{tabular}

The quality of ready drink was assessed by organoleptic parameters. It has clear, malt flavor with brightly expressed hop bitterness and refreshing needle note.

The foaming of ready beer: foam height is $30 \mathrm{~mm}$, foam stability $-3,0 \mathrm{~min}$. Food value of beer "Smaragd" is 4,6 g/100 g, energetic value - $42 \mathrm{kcal} / 100 \mathrm{~g}$.

The results of calculation of chromatograms showed methanol concentration in sample with needle extract addition 2,5 times less than in one, produced according to traditional technology. The addition of needle extract decreases methanol ratio in beer and diminishes its negative effect on organism.

The following stage of the work was the study of physical-chemical parameters and biological value of ready drink (Table 4).

Table 4

Physical-chemical parameters and biological value of $10 \%$ lager "Smaragd"

\begin{tabular}{lc}
\hline \multicolumn{1}{c}{ Name of parameter } & Value \\
\hline Mass share of dry substances in initial wort, $\%$ & 10,3 \\
Mass share of alcohol, $\%$ & 2,9 \\
Acidity, $\mathrm{cm}^{3}, 0,1 \mathrm{~mol} / \mathrm{dm}^{3}$ of sodium hydroxide solution for $100 \mathrm{~cm}^{3}$ of beer & 1,7 \\
Color, $\mathrm{cm}^{3}, 0,1 \mathrm{~mol} / \mathrm{dm}^{3}$ of iodine solution for $100 \mathrm{~cm}^{3}$ of water & 1,2 \\
Mass share of carbon dioxide, $\%$ & 0,3 \\
Stability, days: & 35 \\
Filtered, pasteurized & 5 \\
Unfiltered non-pasteurized, clarified & 3 \\
Unfiltered, non-pasteurized, non-clarified & 3,52 \\
Ascorbic acid content, mg/100 g & 178,1
\end{tabular}

For studying the influence of needle extract on specific properties of beer the antioxidant system of organism of biological object was assessed. The experiments were carried out on animals 
of both sexes at intra-abdominal administration that is provided for using beer on practice and is expedient taking into account the casual situations, causing accidents, suicidal and criminal intoxication or abuse of alcoholic drinks [22].

The administration of beer, produced according to classic technology to rats reliably increased the content of prooxidant markers in liver homogenate comparing with animals, received DC placebo, by $20,4 \%$, TBA-reactant - by $51,6 \%$. At the same time catalase activity decreased by $40,9 \%$. The markers of liver homogenate of animal, received beer with needle extract under conditions of oxidative stress modeling, were within physiological norm (Table 5).

\section{Table 5}

The results of the study of prooxidant markers in liver homogenate of rats after administration of studied drinks, $n=6$

\begin{tabular}{|c|c|c|c|c|c|}
\hline No group & $\begin{array}{l}\text { Administered } \\
\text { substance }\end{array}$ & $\begin{array}{l}\text { Diene conjugates } \\
(\mathrm{mcmol} / \mathrm{g})\end{array}$ & $\begin{array}{l}\text { TBA-reactants } \\
(\mathrm{mcmol} / \mathrm{g})\end{array}$ & $\begin{array}{l}\text { Restored glutathi- } \\
\text { one }(\mathrm{mmol} / \mathrm{g})\end{array}$ & $\begin{array}{l}\text { Catalase activity } \\
(\mathrm{mcmol} / \mathrm{min} \cdot \mathrm{m})\end{array}$ \\
\hline \multicolumn{6}{|c|}{ Group of intact control animals } \\
\hline 1 & Refined water & $9,8 \pm 0,8$ & $6,2 \pm 0,6$ & $13,2 \pm 0,4$ & $6,1 \pm 0,8$ \\
\hline 2 & $\begin{array}{l}\text { Beer, produced by } \\
\text { classic technology }\end{array}$ & $11,8 \pm 0,5^{*}$ & $9,4 \pm 0,7^{*}$ & $12,4 \pm 1,2$ & $3,6 \pm 1,1^{*}$ \\
\hline 3 & $\begin{array}{l}\text { Beer with Pinus syl- } \\
\text { vestris needle extract }\end{array}$ & $9,2 \pm 0,9$ & $6,9 \pm 0,3$ & $13,6 \pm 1,5$ & $5,6 \pm 0,8$ \\
\hline \multicolumn{6}{|c|}{ Groups of animals with modeled pathology } \\
\hline 4 & Refined water & $21,4 \pm 1,9$ & $16,8 \pm 0,9$ & $5,6 \pm 0,5$ & $2,1 \pm 0,4$ \\
\hline 5 & $\begin{array}{l}\text { Beer, produced by } \\
\text { classic technology }\end{array}$ & $26,5 \pm 1,5^{*}$ & $19,1 \pm 1,2^{*}$ & $4,2 \pm 0,8^{*}$ & $1,8 \pm 0,6$ \\
\hline 6 & $\begin{array}{l}\text { Beer with Pinus syl- } \\
\text { vestris needle extract }\end{array}$ & $22,3 \pm 0,7$ & $16,5 \pm 1,4$ & $5,3 \pm 0,4$ & $2,0 \pm 0,5$ \\
\hline
\end{tabular}

Note: * the change is probable relative to the values of animals in groups, received placebo (water): for intact control animals index of group No 1, for animals with control pathology - the index of group No $4(p<0,05)$

White non-linear animals, received classic beer on the model of normobaric hypoxia, demonstrated the reliable decrease of mean life duration by $313,1 \mathrm{~s}$ at oxygen insufficiency comparing with animals, received the refined water. It can be explained by the fact that on the background of alcohol abuse the negative influence of hypoxia on brain intensifies and the processes of peroxide oxidation of lipids in brain tissues are potentiated. The mean life duration of animals, administered with beer with needle extract, remained on the level of intact indices and had no reliable deviations (Table 6).

Table 6

The results of the study of influence of studied drinks on the model of normobaric hypoxia

\begin{tabular}{cc}
\hline Experimental group $(\mathbf{n}=\mathbf{6})$ & Mean life duration of animals $(\mathbf{M} \pm \mathbf{m}), \mathbf{s}$ \\
\hline Intact control (refined water) & $1523,5 \pm 67,1$ \\
Beer, produced by classic technology & $1210,4 \pm 45,9^{*}$ \\
Beer with pine needle extract & $1498,6 \pm 52,4$
\end{tabular}

Note: * the change is probable relative to the values of animals of intact control group $(p<0,05)$ 
The assessment of the influence of pine needle extract addition on beer properties under conditions of acute pathological process testifies that taking of this product instead of beer, produced according to classic technology, can decrease the drink oxidative influence on brain.

\section{Results}

The offered methodology of needle extract can be applied at brewing or low-alcohol enterprises, because its realization doesn't need any additional means. The offered vegetable raw material can be used as an alternative of hop.

The needle extract was introduced in wort at the stage of main fermentation that allows get new original beer with refreshing needle note. The content of pine needle in the receipt of beer "Smaragd" in recalculation on sublimation substance is no more than $20 \%$ by mass from the rated norm of hop, enough for preserving bitterness and smell of hop. The addition of needle extract favors the decrease of methanol content, increases the content of biologically active substances of ready drink.

The elaborated beer due to its antioxidant properties decreases the toxic influence of alcohol on living organism and is the new modern drink of beer market. The drink was administered to animals in dose $15 \mathrm{~g} / \mathrm{kg}$, equivalent to the mean quantity of beer, taken by human at a time. The studies were carried out during 14 days that corresponds to 2 months of use in humans.

\section{Conclusions}

The studies favor the receiving of the new sort of beer and the possibility of widening the assortment of drinks of brewing branch. The use of Pinus sylvestris needle extract at beer production has positive influence on the ready drink quality because it is a source of natural antioxidants, has high food and biological value and may be used as an alternative of hop.

The receipt content and technological instruction for production of $10 \%$ lager "Smaragd" TI 14297558-340:2016 were accepted at the meeting of Specialized branch tasting commission for assessment of quality of beer, non-alcoholic, low-alcoholic drinks, mineral and drinking waters, syrups, Ukrbeer, 15.09.2016.

This scientific research was probated in production conditions at brewing enterprise "OLNA" (Kharkiv city), the patent of Ukraine for effective model No 109200 "The method of brewing beer "Smaragd" was received.

The introduction of needle extract that has vegetable antioxidants in brewing technology is the one of ways of increasing antioxidant capacity of ready drink. It opens the prospect for studies, directed on elaboration of the measures of stabilization of different sorts of beer that may be introduced in production with positive effect on the quality of this food product.

\section{Acknowledgments}

The work was supported by "OLNA" LTD, Kharkic city (Ukraine) and Central scientific laboratory of National pharmaceutical university of Kharkiv city (Ukraine).

\section{References}

[1] Penkina, N., Tatar, L., Zaychenko, G., Lytkin, D. (2015). Research of the toxicological and pharmacological effects of new blends on the body of biological objects. Ukranian Food Journal, 4 (4), 577-586.

[2] Sydor, V., Koshova, V., Boiarska, O., Lavna, M. (2015). Research of beer quality with the addition of elder sap. Technology Audit and Production Reserves, 4 (4 (24)), 52-55. doi: 10.15587/23128372.2015.47701

[3] Danilova, L., Melet'ev, A., Berezka, T., Arutyunyan, T. (2013). Antioxidants from plant materials in the technology of beer stabilization. Eastern-European Journal of Enterprise Technologies, 4 (10 (64)), 23-26. doi: 10.15587/1729-4061.2013.1630

[4] Zubareva, Ye. V. (2013). Sezonnaya izmenchevost' vitamina S v khvoye sosny obyknovennoy $\mathrm{v}$ usloviyakh g. Krasnoyarska [Seasonal variability of vitamin C in needles of Scots pine in conditions of Krasnoyarsk]. Vesnik KrasGAU, 4, 70-73.

[5] DSTU 3888:2015. Pyvo. Zahal'ni tekhnichni umovy [Beer. General specifications]. (2015). Kyiv: UkrNDNTS, 14. 
[6] DSTU 7104:2009. Pyvo. Metody vyznachannya spyrtu, diysnoho ekstraktu ta rozrakhovuvannya sukhykh rechovyn u pochatkovomu susli [Methods for determination of spirit, actual extract and estimation of dry substances in the initial must]. (2009). Kyiv: Derzhspozhyvstandart, 20.

[7] DSTU 4852:2007. Pyvo. Metody vyznachennya kyslotnosti [Beer. Methods for determination of acidity]. (2007). Kyiv: Derzhspozhyvstandart, 10.

[8] DSTU 4851:2007. Pyvo. Metody vyznachennya kol'oru [Beer. Methods for determination of color]. (2007). Kyiv: Derzhspozhyvstandart, 16.

[9] DSTU 4850:2007. Pyvo. Metody vyznachennya dioksydu vuhletsyu ta stiykosti [Beer. Methods for determining dioxin emissions and sustainability]. (2007). Kyiv: Derzhspozhyvstandart, 16.

[10] Orlova, N. Ya., Mandryka, V. I. (2008). Teoretychni osnovy tovaroznavstva. Prodovol'chi tovary [Theoretical Foundations of merchandise. Groceries]. Kyiv: KNTEU, 145.

[11] DSTU 4222:2003. Horilky, spyrt etylovyy ta vodno-spyrtovi rozchyny. Hazokhromatohrafichnyy metod vyznachennya vmistu mikrokomponentiv [Vodka, ethyl alcohol and water-alcohol solution. Chromatographic method for determination of micro]. (2003). Kyiv: Derzhspozhyvstandart, 14.

[12] DSTU 4646:2006. Spyrt etylovyi, horilky, napoi likero-horilchani. Hazokhromatohrafichnyi metod vyznachannia spravzhnosti [Ethyl alcohol, vodka, drinks liquor. Chromatographic method for determining authenticity]. (2006). Kyiv: Derzhspozhyvstandart, 19.

[13] Halafyan, A. A. (2007). STATISTICA 6. Statisticheskij analiz dannyh [Statistical analysis of the data]. Ed. 3. Moscow: Binom-Press, 512.

[14] Skornyakov, V. I., Kozhemyakin, L. A., Smirnov, V. V. (1988). Produkty perekisnogo okisleniya lipidov u bol'nyh s cherepno-mozgovoj travmoj [The products of lipid peroxidation in patients with craniocerebral trauma]. Laborotornoe delo, 8, 14-16.

[15] Stal'naya, I. D., Garishvili, T. G. (1977). Metod opredeleniya dienovoj kon"yugacii nenasyshchennyh vysshih zhirnyh kislot [Method for determination of diene conjugation of unsaturated higher fatty acids]. Sovremennye metody v biohimii. Moscow: Medicina, 43-44.

[16] In: Karpishchenko, A. I. (1997). Spektorofotometricheskoe opredelenie produktov perekisnogo okisleniya lipidov Medicinskaya laboratornaya diagnostika (programmy i algoritmy) [Spectrophotometric determination of lipid peroxidation products. Medical laboratory diagnostics (programs and algorithms)]. St. Petersburg: Intermedika, 48-52.

[17] Stal'naya, I. D., Garishvili, T. G. (1977). Metod opredeleniya malonovogo dial'degida s pomoshch'yu tiobarbiturovoj kisloty [Method for the determination of malonic dialdehyde with thiobarbituric acid]. Sovremennye metody v biohimii. Moscow: Medicina, 66-68.

[18] In: Severina, S. E., Solov'evoj, T. A. (1989). Praktikum po biohimii Opredelenie chisla sul'fgidril'nyh grupp s reaktivom EHllmana [Determination of the number of sulfhydryl groups with the Ellman reagent]. Moscow: MGU, 160-161.

[19] Baraboj, V. A., Orel, V. E., Karnauh, I. M. (1991). Perekisnoe okislenie i radiaciya. Metodicheskie osobennosti issledovaniya perekisnogo okisleniya [Methodological features of the study of peroxidation]. Kyiv: Naukova dumka, 52-75.

[20] Korolyuk, M. A., Ivanova, L. I., Majorova, I. G., Tokarev, V. E. (1988). Metod opredeleniya aktivnosti katalazy [Method for determination of catalase activity]. Laboratornoe delo, 1, 16-19.

[21] In: Habrieva, R. U. (2005). Rukovodstvo po ehksperimental'nomu (doklinicheskomu) izucheniyu novyh farmakologicheskih veshchestv [Manual on experimental (preclinical) study of new pharmacological substance]. Ed. 2. Moscow: Medicina, 832.

[22] Kovalenko, V. M. (2009). Doklinichni doslidzhennya likars’kykh zasobiv v Ukrayini [Preclinical studies of medicines in Ukraine]. Farmakolohiya ta likars'ka toksykolohiya, 5 (12), 56-61. 